\title{
Changes on Potato Leaf Metabolism and Anatomy Induced by Plant Growth Regulators
}

\author{
Fernanda F. Araujo ${ }^{1}$, Mirelle N. Santos ${ }^{1}$, Lucas C. Costa $^{1}$, Karoliny F. Moreira ${ }^{1}$, Maicon N. Araujo ${ }^{1}$, \\ Paola A. H. Martinez ${ }^{1} \&$ Fernando L. Finger ${ }^{1}$ \\ ${ }^{1}$ Universidade Federal de Viçosa, Viçosa, Minas Gerais, Brazil \\ Correspondence: Fernanda F. Araujo, Federal University of Viçosa, Viçosa, Minas Gerais, Brazil. E-mail: \\ fernandaufv@hotmail.com
}

Received: May 21, 2018

doi:10.5539/jas.v11n7p139
Accepted: April 4, 2019 Online Published: May 31, 2019

URL: https://doi.org/10.5539/jas.v11n7p139

The research is financed by CNPq and FAPEMIG.

\begin{abstract}
The use of growth regulators in potato crop is an alternative to reduce the aerial growth of plants and redirects carbon assimilates and nutrients to the tubers. Therefore, the objective of this study was to evaluate the effects of growth regulators, paclobutrazol and trinexapac-ethyl on plant growth and changes on the anatomy of leaves of cultivar Markies in summer conditions of the southern region of Brazil. Potato plants cv. Markies were in the summer growing season of Southeast region of Brazil and 35 days after planting, the plants were sprayed with paclobutrazol (PBZ) at 0.125 and $0.250 \mathrm{~L} \mathrm{ha}^{-1}$ and trinexapac-ethyl (TE) at 1.0 and $2.0 \mathrm{~L} \mathrm{ha}^{-1}$. Treatment with PBZ at both doses reduced the height of potato plants, which resulted in higher index of leaf chlorophyll and reduced the content of starch and non-reducing sugars. Both PBZ and TE treated plants exhibited anatomical changes in the leaves, including larger epidermal cells and more elongated palisades cells. These data suggest that such changes in the anatomy of potato leaf in response to the use of PBZ directly influence leaf metabolism.
\end{abstract}

Keywords: gibberellin, cultivar markies, Chlorophyll, foliar metabolism

\section{Introduction}

Total production of dry matter by potato plant and its distribution among the different organs of the plant are important factors on the yield of tubers (Silva et al., 2009). Potato is mainly a temperate climate plant, which perform poorly under warm weather conditions. Potato production depends on the ability of the plant to synthesize carbohydrates in the leaves and mobilize them into the growing tubers (Geigenberger et al., 2004; Bahaji et al., 2014). However, one of the factors that restrict higher yields is related to excessive growth of the aerial parts in detriment to smaller growth of the tubers (Prakash et al., 2001). Because potato is mainly a temperate climate plant, which performs poorly under warm weather conditions, most cultivars present greater vegetative growth, favoring the growth of the aerial part of the plants. The adoption of management practices that may reduce the size of the plants can be an alternative to increase the yield of tubers, which can be achieved by applying plant growth regulators, to reduce plant height (Rademacher, 2000).

Most commercial plant regulators inhibit the synthesis of gibberellins and can be used to reduce stem elongation and reduce the vegetative growth. Three different types of plant growth regulators that interfere with the synthesis of gibberellins are related, like the quaternary compounds, including mepiquat chloride and chlormequat chloride, by inhibiting the conversion of geranyl geranyl difastrate to the caurene (Rademacher, 2000).

Paclobutrazol (PBZ) is one of the most active chemicals to reduce GA synthesis, and alters the growth of several species of plants, mainly by reducing the plant height. PBZ blocks oxidation reactions in the pathway of GA synthesis, promoting a number of physiological changes in plants, including carbohydrate partitioning (Fletcher et al., 2000; Tekalign \& Hammes, 2005). PBZ induces morphological and anatomical modifications of the leaf, depending on the plant species, stage of growth, rate and method of application. Other effects of PBZ include reduction of leaf area (Sebastian et al., 2002; Yeshitela et al., 2004), increases epicuticular wax layer thickness (Jenks et al., 2001) and vascular bundle size (Sopher et al., 1999). In peanut (Arachis hypogaea L.), leaves treated 
with PBZ exhibited well differentiated palisade and spongy mesophyll layers with longer and longer cells (Sankar et al., 2016).

Trinexapac-ethyl (TE) has similar effects of PBZ on several species belonging to the Poaceae family (Fialho et al., 2009). This product interferes with the inhibition of the $3 \beta$-hydroxylase enzyme, reducing the active gibberellic acid $\left(\mathrm{GA}_{1}\right)$ and increasing its $\mathrm{GA}_{20}$ immediate biosynthetic precursor, causing reduction of the cellular elongation of the plants during the vegetative stage (Heckman et al., 2002).

For potato crop, the application of growth regulating products can be used as an alternative to reduce the aerial growth of the plants during summer season in Brazil, and to increase the mobilization of assimilates and nutrients for the tubers formation, and reduction of transpiration rates and consequently better water use efficiency (Awati et al., 2016; Mabvongwe et al., 2016; Bhattarai, 2017). Therefore, the objective of this study was to evaluate the effects of growth regulators, paclobutrazol and trinexapac-ethyl on plant growth and the anatomy of leaves of cultivar Markies in summer conditions of the southern region of Brazil.

\section{Material and Methods}

The experiment was carried out with the cultivar Markies and conducted in a potato field located in Perdizes $\left(19^{\circ} 21^{\prime} 19^{\prime \prime} \mathrm{S}, 47^{\circ} 16^{\prime} 58^{\prime \prime} \mathrm{W}\right)$, Minas Gerais, Brazil, during the summer season.

Thirty days before planting, the seed potatoes were removed from the cold room $\left(4{ }^{\circ} \mathrm{C}\right.$ and $85 \%$ relative humidity $)$ and placed at room temperature in the dark to induce spontaneous sprouting of the tubers. The planting was mechanized with spacing of $0.38 \mathrm{~m}$ between plants, $0.8 \mathrm{~m}$ between rows and planting depth of $0.12 \mathrm{~m}$. The experimental plots consisted of $19.2 \mathrm{~m}^{2}$, being $2.4 \mathrm{~m}$ wide and $8 \mathrm{~m}$ long, and a longitudinal distance of $4 \mathrm{~m}$ between the plots was always maintained.

Before planting it was applied $180 \mathrm{~kg} \mathrm{ha}^{-1}$ of N (MAP and ammonium nitrate), $420 \mathrm{~kg} \mathrm{ha}^{-1}$ of $\mathrm{P}_{2} \mathrm{O}_{5}$ (MAP) and 270 $\mathrm{kg} \mathrm{ha}^{-1}$ of $\mathrm{K}_{2} \mathrm{O}$ (potassium chloride). Potassium nitrate was applied at 35 and 65 days after planting. All treatments received micronutrient applications, via central pivot, throughout the cycle.

Thirty-five days after planting, the plants were sprayed with PBZ at 0.125 and $0.250 \mathrm{~L} \mathrm{ha}^{-1}$ and trinexapac-ethyl (TE) at 1.0 and $2.0 \mathrm{~L} \mathrm{ha}^{-1}$ using the formulation Cement (250 g a.i. PBZ per liter, Syngenta Crop Protection) and Moddus ( $250 \mathrm{~g}$ a.i. Trinexapac-ethyl per liter, Syngenta Crop Protection). During the application, a constant pressure was applied in the costal sprayer $\left(\mathrm{CO}_{2}\right)$ with a bar of four nozzles spaced $0.5 \mathrm{~m}$ apart and $0.5 \mathrm{~m}$ in relation to the plants, at an average rate of $4 \mathrm{~km} \mathrm{~h}^{-1}$. The control treatment plants were sprayed with water with equivalent volumes.

The evaluations were carried out at 50, 65, 80 and 95 days after planting (DAP). Optical measurements of leaf chlorophyll and flavonoids were made on the leaflet of the fourth leaf completely expanded from the apex of the plant with the portable meter Dualex ${ }^{\circledR}$ (Force-A, Orsay, France), obtaining the Flavonoid Index (FLVI), the Chlorophyll Index (CHLI) and the Nitrogen Balance Index (NBI). The latter was obtained by the relationship between CHLI and FLVI.

The quantification of total soluble sugars of leaves and tubers was carried out according to the phenol-sulfuric acid method (Dubois et al., 1956). Reducing sugars were quantified according to the dinitrosalicylic acid (DNS) method (Gonçalves et al., 2010). The non-reducing sugar content was obtained by the difference between the total soluble sugar content and the reducing sugar content. For the quantification of starch, the method used was described by McCready et al. (1950).

Potato leaf sections were collected at 65 DAP and fixed at FAA50 for 48 hours and maintained in $70 \%$ ethanol (Johansen, 1940), with three replicates per treatment. Samples $(0.25 \times 0.25 \times 0.25 \mathrm{~mm})$ were dehydrated in ethanolic series and embedded in methacrylate (Historesin, Leica, Heidelberg, Germany) according to the manufacturer's recommendations. The material was sectioned $5 \mu \mathrm{m}$ thick on an automated rotary microtome (Leica RM2155, Deerfield, IL, USA) and stained with toluidine blue (O'Brien et al., 1964). The images were obtained in light microscopy (AX-70 TRF, Olympus Optical, Tokyo, Japan) coupled to a digital camera (Zeiss AxioCam HRc, Göttinger, Germany) to the computer with the Axion Vision image capture program. Measurements were taken using Image-Pro Plus software.

The experiment was conducted in a split plot design, with the plots comprising the different concentrations of growth regulators and the subplots the plant evaluation times, in a completely randomized design with three repetitions and each experimental unit consisted of two plants. The data were submitted to analysis of variance (ANOVA) and regression using the System of Statistical Analysis and Genetics of the UFV (Saeg, 2008). The regression model was based on the significance of the regression coefficients using the test-t at $5 \%$ probability, the 
coefficient of determination $\left(\mathrm{R}^{2}\right)$, and on the biological phenomenon under study. The means were compared by the Tukey test at $5 \%$ probability.

\section{Results and Discussion}

Control plants presented longer stem length throughout the whole crop cycle, while the TE treated plants presented intermediate values and the plants treated with PBZ had the shortest length for the main stem (Figure 1A). The application of 0.125 and $0.250 \mathrm{~L} \mathrm{ha}^{-1}$ of PBZ reduced by $14 \%$ and $20 \%$ of plant height relative to the control, respectively.

Triazoles are potent plant regulators capable to inhibit shoot growth at low concentrations. The PBZ effectively suppresses growth in a wide range of plant species, where treated plants tend to be smaller and more compact in appearance and have darker green leaves (Esmaielpour et al., 2011; Brito et al., 2016; Rahman et al., 2016; Hamdani et al., 2018). Growth reduction occurs mainly due to decreased internodes length and the effective dose varies with the species and cultivar (Davis \& Curry, 1991).
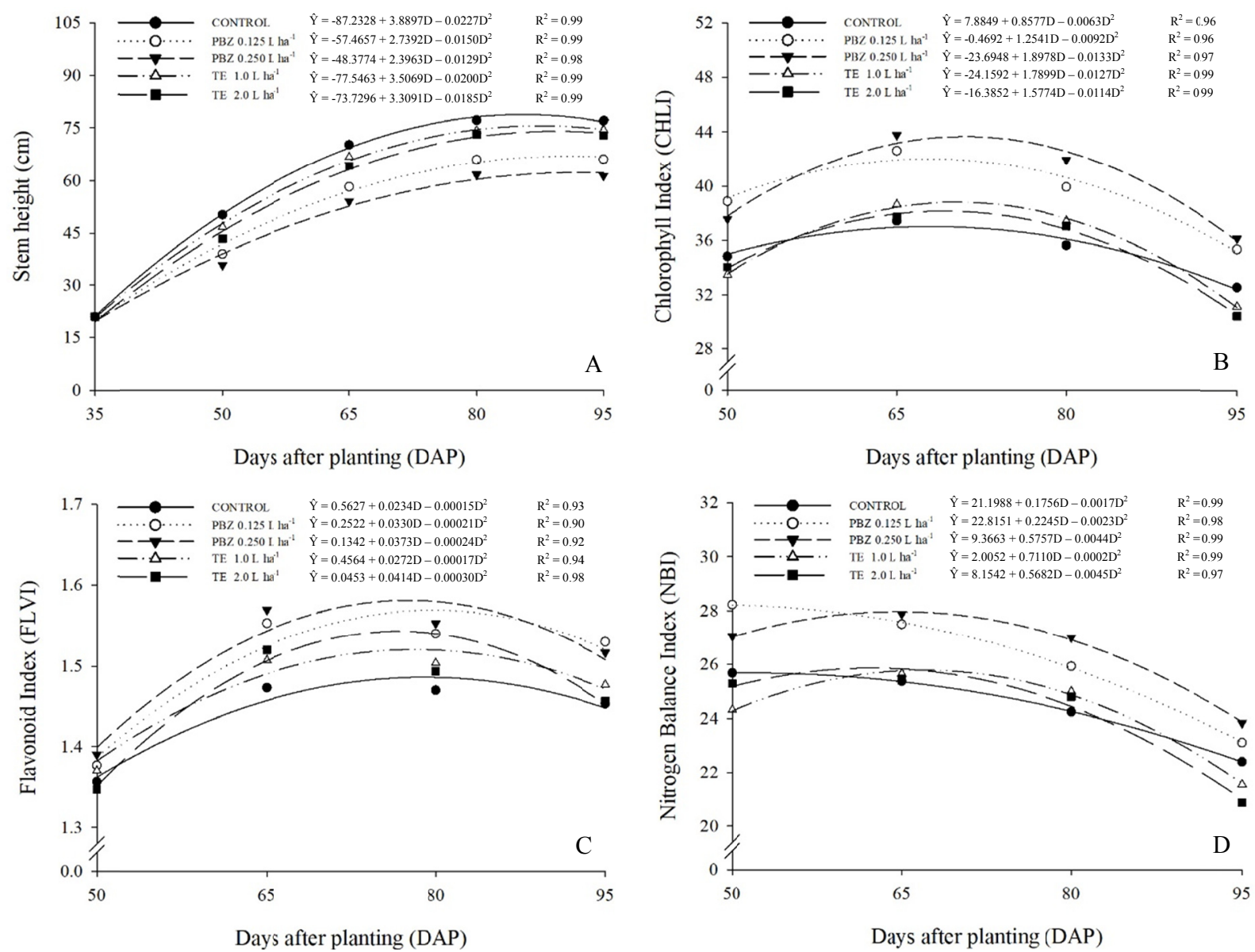

Figure 1. Stem length (A), chlorophyll index (B), flavonoid index (C) and nitrogen balance index (D) of potato plants treated with paclobutrazol (PBZ), trinexapac-ethyl (TE) and control over the days after planting

The chlorophyll index (CHLI) increased in all treatments with PBZ, reaching a maximum index between 68 and 72 days after planting, followed by a decrease, indicating the beginning of the leaf senescence process (Figure 1B). Foliage of potato plants treated with PBZ exhibited darker green color compared to plants treated with TE or control in all the evaluations. The highest chlorophyll content was observed in leaves treated with PBZ at $0.250 \mathrm{~L}$ $\mathrm{ha}^{-1}$ at 68 DAP; the CHLI of this treatment was $15.5 \%$ higher than in the leaves of the control plants at the same date of analysis (Figure 1B). The darker green foliage of the PBZ-treated plants could be due to increased chlorophyll synthesis (Sebastian et al., 2002) and/or higher chloroplast density per unit area of leaf (Khalil, 1995). The higher chlorophyll content in potato leaves treated with PBZ compared to control leaves may be related to its 
influence on endogenous cytokinin. It has been proposed that PBZ stimulates the synthesis of cytokinin, which induces chloroplast differentiation, chlorophyll biosynthesis and prevents chlorophyll degradation (Fletcher et al., 2000). The use of inhibitors of GA biosynthesis, such as uniconazole, ancymidol and paclobutrazol, increased the cytokinin content in rice (Izumi et al., 1988), soybean (Grossman, 1992) and clove plants (Sebastian et al., 2002).

Plants treated with PBZ had the highest flavonoid indexes (FLVI) in all the evaluations (Figure 1C). PBZ belongs to the triazole chemical group and has antifungal action. According to Fletcher et al. (2000), PBZ can also increase the tolerance of different plant species to biotic and abiotic stresses, including low and high temperature conditions. There is some evidence that components of the photosynthesis system and molecules that regulate some constituents of the antioxidant activity in plants are the main targets of triazoles, as a way to increase plant tolerance to stress (Kraus \& Fletcher, 1994; Lin et al., 2006). This indicates that the higher FLVI observed in plants treated with PBZ during the cycle of the crop may have been caused by the activation of the defense mechanism.

In those plants treated with highest dose of TE, an increase of FLVI was determined, reaching maximum content at 69 DAP, followed by a marked decrease up to the 95 DAP, but not differing from the control at the same date (Figure 1C). The trinexapac-ethyl presents structural similarities with 2-oxoglutaric acid and can compete with dioxigenases that are dependent on 2-oxoglutaric acid for the formation of gibberellins and metabolism of flavonoids (Rademacher, 2000). Thus, anthocyanins and other flavonoids have been reported as the biochemical targets of the acylcyclohexanedione compounds. Inhibition of 2-oxyglutarate-dependent dioxygenases, such as flavanone 3-hydroxylase, may lead to an alternative pathway in phenylpropanoid metabolism and cause considerable changes in the spectrum of flavonoids and related compounds in plants treated with trinexapac-ethyl (Rademacher et al., 2006).

Throughout the crop cycle, a higher index of nitrogen balance (NBI) was present in leaves of plants treated with PBZ (Figure 1D). These results indicate that these plants might have greater assimilation of nitrogen by the leaves. The remobilization of photoassimilates and nitrogen from the aerial part to the tubers at the end of growing cycle is considered as a factor that affects the final production of tubers (Moorby, 1970).

In the control and PBZ treated plants at rate of $0.125 \mathrm{~L} \mathrm{ha}^{-1}$, a decrease in the NBI leaf occurred throughout the evaluations. Meanwhile, treatments with $0.250 \mathrm{~L} \mathrm{ha}^{-1}$ of PBZ and with both doses of TE showed slight increase in the NBI between 50 and 65 days, followed by decrease until the end of the evaluations.

Plants treated with 1.0 $\mathrm{L} \mathrm{ha}^{-1} \mathrm{TE}$ and control had the highest total soluble sugars contents in leaves at 50 DAP (Figure 2A). With the exception of the leaves treated with TE $2.0 \mathrm{~L} \mathrm{ha}^{-1}$, the remaining treatments showed a drop at 65 DAP, followed by an increase on total soluble sugars contents in all treatments until the end of the evaluations.

The highest percentage of reducing sugars occurred at 50 DAP in control leaves and the lowest content in the leaves of plants treated with PBZ $0.250 \mathrm{~L} \mathrm{ha}^{-1}$ (Figure 2B). For this treatment, these sugars increased during the evaluation days, reaching the highest content at 95 DAP. Plants treated with $1.0 \mathrm{~L} \mathrm{ha}^{-1} \mathrm{TE}$ had the highest non-reducing sugars content at 50 DAP (Figure 2C). For all treatment the lowest level for non-reducing sugars was at 65 DAP, with a subsequent increase up to 95 DAP. 

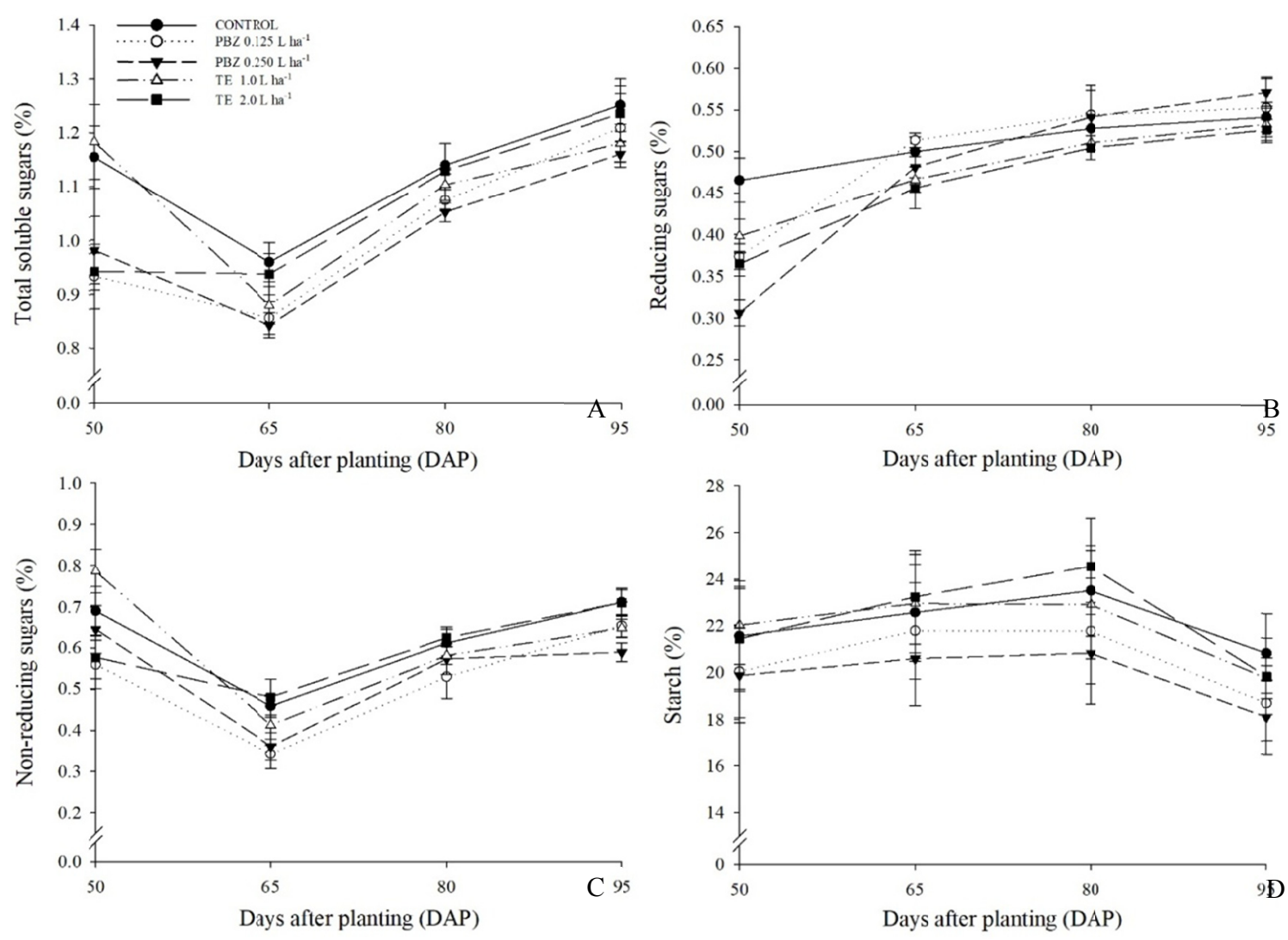

Figure 2. Total soluble sugars (A), reducing sugars (B), non-reducing sugars (C) and starch (D) in leaves of potato plants treated with paclobutrazol (PBZ), trinexapac-ethyl (TE) and control according to days after planting. The vertical bars represent the standard error of the mean

Treatment of plants with $0.250 \mathrm{~L} \mathrm{ha}^{-1}$ of PBZ resulted in the lowest leaf starch content in all evaluations (Figure 2D). Starting at $80 \mathrm{DAP}$, leaf starch content declined in all treatments, indicating possible remobilization of leaf reserves to the tubers. According to Moorby (1970), the distribution of photoassimilates stored in other organs of the plant, mainly leaves and stems, has considerable importance in bulking the tubers, being therefore an important factor on the final yield. This same author verified that during the period of decrease on dry matter of the aerial part, determined increments of 20 to $25 \%$ on the dry mass of the tubers due to the remobilization of photoassimilates. At the end of the vegetative cycle, $90 \%$ of the dry matter found in the tubers resulted from the direct translocation of photoassimilates and $10 \%$ from the remobilization of photoassimilates stored in the aerial part of the plant.

Plants treated with PBZ (Figures 3B and 3C) and TE (Figures 3D and 3E) exhibited larger epidermal cells and the single layer of palisade mesophyll cells were more elongated compared to the control (Figure 3A). In the treatments with PBZ the spongy mesophyll was thicker than the other treatments. 


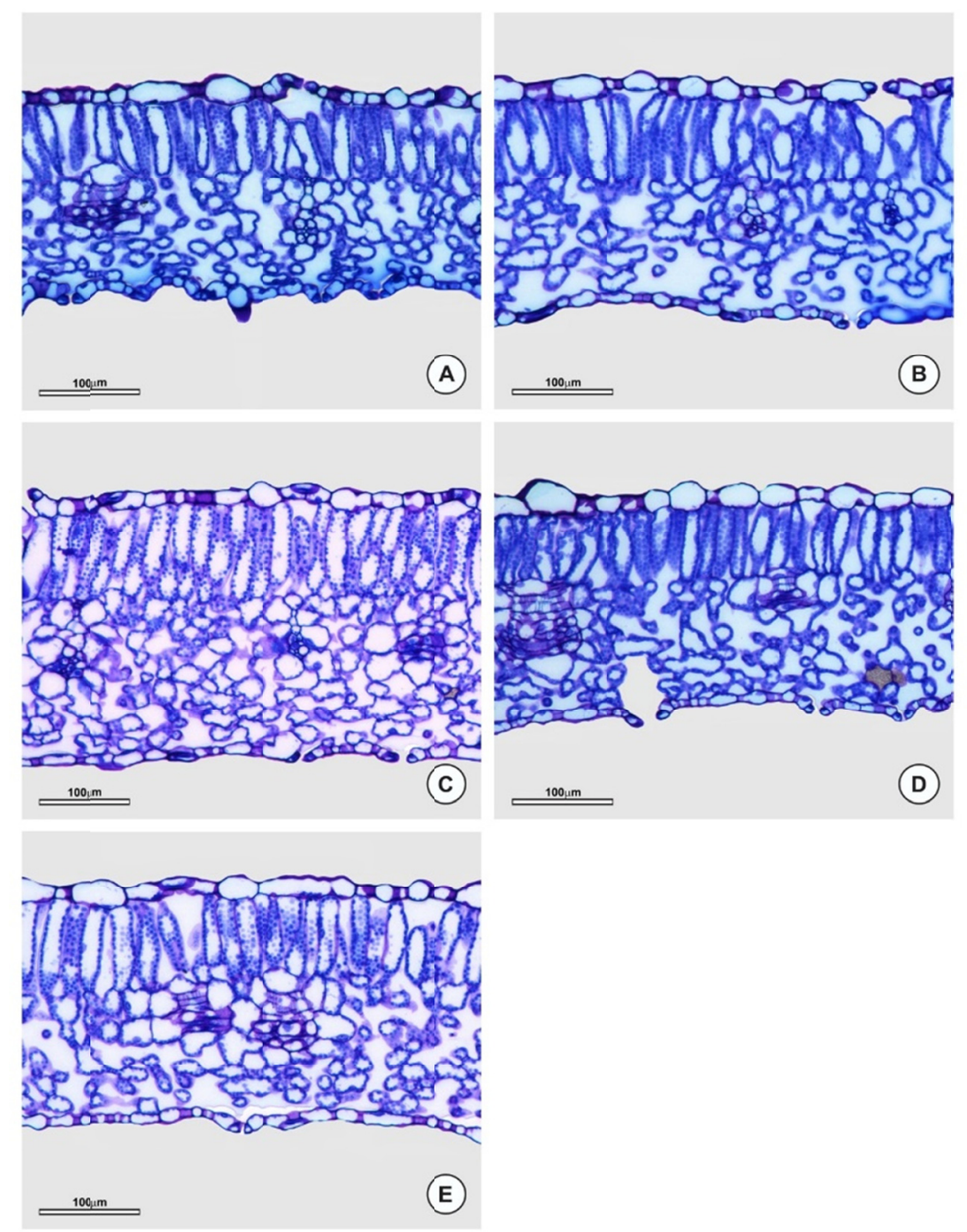

Figure 3. Light micrographs of transverse sections of control potato leaves (A) and sprayed with paclobutrazol (PBZ) at doses of $0.125(\mathrm{~B})$ and $0.250 \mathrm{~L} \mathrm{ha}^{-1}(\mathrm{C})$ and trinexapac-ethyl (TE) at doses of $1.0(\mathrm{D})$ and $2.0 \mathrm{~L} \mathrm{ha}^{-1}(\mathrm{E})$. Scale bar $=100 \mu \mathrm{m}$

Compared to control leaves, leaf thickness increased by $29.1 \%$ in response to treatment with the highest PBZ dose and by $10.9 \%$ to the highest of TE dose (Table 1). Tsegaw et al. (2005) also observed that potato plants cv. Zemen treated with PBZ at the dosage of $67.5 \mathrm{mg}$ a.i. per plant increased total leaf thickness from 215 to $267 \mu \mathrm{m}$ bringing about $24 \%$ increase higher than the control. Trinexapac-ethyl, on the other hand, promoted anatomical changes in Brachiaria brizantha, increasing the thickness of the leaf blade and the mesophyll area (Fialho et al., 2009).

The PBZ increased in the length (ECL) and in the epidermal cell width (ECW) were 13 and $12 \%$ higher with 0.250 $\mathrm{L} \mathrm{ha}^{-1}$ and 10 and $11 \%$ in plants sprayed with $0.125 \mathrm{~L} \mathrm{ha}^{-1}$ respectively, compared to control (Table 1). In leaves treated with the growth regulator TE, this increase was approximately 18 and $15 \%$ in the dosage $2.0 \mathrm{~L} \mathrm{ha}^{-1}$ and 16 and $13 \%$ in the dosage $1.0 \mathrm{~L} \mathrm{ha}^{-1}$, respectively.

PBZ and TE treatments increased the palisade cells length (PCL), but did not significantly alter the width (PCW) of these cells. The increase in CCP was $24 \%\left(0.125 \mathrm{~L} \mathrm{ha}^{-1}\right)$ and $26.9 \%\left(0.250 \mathrm{~L} \mathrm{ha}^{-1}\right)$ for leaves treated with PBZ, and $15.8 \%\left(1.0 \mathrm{~L} \mathrm{ha}^{-1}\right)$ and $17.2 \%\left(2.0 \mathrm{~L} \mathrm{ha}^{-1}\right)$ for TE-treated leaves compared to untreated leaves (Table 1).

Treatment with PBZ increased the leaf spongy mesophyll thickness (SMT) in $34.6 \%$ for the rate of $0.250 \mathrm{~L} \mathrm{ha}^{-1}$ and by $21.3 \%$ for those treated with $0.125 \mathrm{~L} \mathrm{ha}^{-1}$ compared to control (Table 1). Treatments with TE did not differ significantly from the control. 
Kishorekumar et al. (2006) studying the anatomy of Chinese potato leaves (Solenostemon rotundifolius) treated with PBZ determined that the thickness of the upper and lower epidermis were increased, as well as the length of the palisade and spongy cells and the number of stomata. The authors concluded that the use of triazoles, such as PBZ, may be a useful tool for reducing the rate of transpiration and to activate drought escape mechanisms in the plant.

Table 1. Effect of paclobutrazol (PBZ) and trinexapac-ethyl (TE) treatments on leaf characteristics. TT: total thickness, ECL: epidermal cell length, ECW: epidermal cell width, PCL: palisade cell length, PCW: palisade cell width, SMT: spongy mesophyll thickness $(\mu \mathrm{m})$

\begin{tabular}{lllllll}
\hline Treatments & TT & ECL & ECW & PCL & PCW & SMT \\
\hline Control & $305.9 \mathrm{c}$ & $49.6 \mathrm{c}$ & $32.1 \mathrm{~b}$ & $111.7 \mathrm{c}$ & $28.4 \mathrm{a}$ & $179.3 \mathrm{c}$ \\
PBZ 0.125 L ha-1 & $346.3 \mathrm{~b}$ & $54.5 \mathrm{~b}$ & $35.5 \mathrm{a}$ & $138.8 \mathrm{a}$ & $32.1 \mathrm{a}$ & $217.5 \mathrm{~b}$ \\
PBZ 0.250 L ha & $394.8 \mathrm{a}$ & $55.9 \mathrm{ab}$ & $35.8 \mathrm{a}$ & $141.7 \mathrm{a}$ & $32.9 \mathrm{a}$ & $241.4 \mathrm{a}$ \\
TE $1.0 \mathrm{~L} \mathrm{ha}^{-1}$ & $314.4 \mathrm{c}$ & $57.6 \mathrm{ab}$ & $36.3 \mathrm{a}$ & $129.4 \mathrm{~b}$ & $30.1 \mathrm{a}$ & $186.8 \mathrm{c}$ \\
TE 2.0 L ha & $339.1 \mathrm{~b}$ & $58.5 \mathrm{a}$ & $36.9 \mathrm{a}$ & $130.9 \mathrm{~b}$ & $31.8 \mathrm{a}$ & $193.4 \mathrm{c}$ \\
CV $(\%)$ & 9.2 & 8.5 & 7.3 & 11.5 & 9.5 & 7.9
\end{tabular}

Note. Means followed by the same lowercase vertical letter do not differ statistically from each other at $5 \%$ probability by the Tukey test.

The impact of PBZ at cellular level was evident on the increase of total leaf thickness, which can be attributed to the increase in epidermal cell diameter, palisade cell length and spongy mesophyll thickness. Meanwhile, the increase in the thickness of the leaves treated with the highest TE dose was due only to the increase in the diameter of the epidermal cells and the length of the palisade cells. The lower degree of anatomical changes in leaves treated with 1.0 $\mathrm{L} \mathrm{ha}^{-1} \mathrm{TE}$ may occurred due to the low concentration of the product.

\section{Conclusion}

Treatment with PBZ reduced the height of potato plants, which presented higher leaf chlorophyll index and reduction in leaf content of starch and non-reducing sugars. Both PBZ and TE treated plants indeced anatomical changes in the leaves, resulting in larger epidermal cells and more elongated palisade cells. These data suggest that such changes in the anatomy of potato leaf in response to the use of PBZ directly influence leaf chlorophyll and carbohydrate metabolism.

\section{References}

Awati, R., Bhattacharya, A., \& Char, B. (2016). Effect of foliar application of plant growth regulators on growth and yield of potato seed tubers propagated from micro plantlets on soilless solid media in greenhouse. Advance Research Journal of Crop Improvement, 7(2), 234-239. https://doi.org/10.15740/HAS/ARJCI/ 7.2/234-239

Bahaji, A., Li, J., Sánchez-López, A. M., Baroja-Fernández, E., Muñoz, F. J., Ovecka, M., Almagro, G., Montero, M., Ezquer, I., Etxeberria, E., \& Pozueta-Romero, J. (2014). Starch biosynthesis, its regulation and biotechnological approaches to improve crop yields. Biotechnology Advances, 32, 87-106. https://doi.org/ 10.1016/j.biotechadv.2013.06.006

Bhattarai, P. (2017). Effects of plant growth regulators on growth and yield of pre-basic seed potato production under glasshouse condition. SAARC Journal of Agriculture, 15(1), 149-160. https://doi.org/10.3329/ sja.v15i1.33161

Brito, C. L. L., Matsumoto, S. N., Santos, J. L., Gonçalves, D. N., \& Ribeiro, A. F. F. (2016). Efeito do paclobutrazol no desenvolvimento de plantas de girassol ornamental. Revista de Ciências Agrárias, 39(1), 153-160. https://doi.org/10.19084/RCA15044

Davis, T., \& Curry, E. (1991). Chemical regulation of vegetative growth. Critical Reviews in Plant Sciences, 10(2), 151-158. https://doi.org/10.1080/07352689109382310

Dubois, M. and Gilles, K. A., Hamilton, J. K., Rebers, P. A., \& Smith, F. (1956). Colorimetric method for determination of sugars and related substances. Analytical Chemistry, 28, 350-356. https://doi.org/ $10.1021 / \mathrm{ac} 60111 \mathrm{a} 017$ 
Esmaielpour, B., Hokmalipour, S., Jalilvand, P., \& Salimi, G. (2011). The investigation of paclobutrazol effects on growth and yield of two potato (Solanum tuberosum) cultivars under different plant density. Journal of Food, Agriculture and Environment, 9, 289-294.

Fialho, C. M. T., Ferreira, E. A., Meira, R. A. S., Santos, J. B., Silva, A. A., Freitas, F. C. L., ... Rocha, P. R. R. (2009). Caracteres morfoanatômicos de Brachiaria brizantha submetida à aplicação de Trinexapac-Ethyl. Planta Daninha, 27(3), 533-539. https://doi.org/ 10.1590/S0100-83582009000300014

Fletcher, R. A., Gilley, A., Sankhla, N., \& Davis, T. (2000). Triazoles as plant growth regulators and stress protectants. Horticultural Reviews, 24, 55-138. https://doi.org/10.1002/9780470650776.ch3

Geigenberger, P., Stitt, M., \& Fernie, A. R. (2004). Metabolic control analysis and regulation of the conversion of sucrose to starch in growing potato tubers. Plant Cell Environment, 27, 655-673. https://doi.org/10.1111/ j.1365-3040.2004.01183.x

Gonçalves, C., Rodrigues-Jasso, M. R., Gomes, N., Teixeira, J. A., \& Belo, I. (2010). Adaptation of dinitrosalicylic acid method to microtiter plates. Analytical Methods, 2, 2046-2048. https://doi.org/10.1039/ c0ay00525h

Grossmann, K. (1992). Plant growth retardants: Their mode of action and benefit for physiological research. In C. M. Karssen, L. C. Van Loon, \& D. Vreugdenhil (Eds.), Plant Growth Regulations (pp.788-797). Kluwer Academic Publishers, The Netherlands. https://doi.org/10.1007/978-94-011-2458-4_97

Hamdani, J. S., Nuraini, A., \& Mubarok, S. (2018). The use of paclobutrazol and shading net on growth and yield of potato 'Medians' tuber of G2 in medium land of Indonesia. Journal of Agronomy, 17, 62-67. https://doi.org/10.3923/ja.2018.62.67

Heckman, N. L., Elthon, T. E., Horst, G. L., \& Gaussoin, R. E. (2002). Influence of trinexapac-ethyl on respiration of isolated wheat mitochondria. Crop Science, 42, 423-427.

Izumi, K., Nakagawa, S., Kobayashi, M., Oshio, H., Sakurai, A., \& Takahashi, N. (1988). Levels of IAA, cytokinins, ABA andethylene in rice plants as affected by GA biosynthesis inhibitor, uniconazole-P. Plant Cell Physiology, 29, 97-104. https://doi.org/10.1093/oxfordjournals.pcp.a077480

Jenks, M. A., Andersen, L., Teusink, R. S., \& Williams, M. H. (2001). Leaf cuticular waxes of potted rose cultivars as affected by plant development, drought and paclobutrazol treatments. Physiology Plant, 112, 62-70. https://doi.org/10.1034/j.1399-3054.2001.1120109.x

Johansen, D. A. (1940). Plant microtechnique (p. 523). New York: Mcgraw-Hill Book.

Khalil, I. A. (1995). Chlorophyll and carotenoid contents in cereals as affected by growth retardants of triazole series. Cereal Research Communications, 23, 183-189.

Kishorekumar, A., Jaleel, C. A., Manivannan, P., Sankar, B., Sridharan, R., Somasundaram, R., \& Panneerselvam, R. (2006). Differential effects of hexaconazole and paclobutrazol on the foliage characteristics of Chinese potato (Solenostemon rotundifolius Poir., J.K. Morton). Acta Biologica Szegediensis, 50, 127-129.

Kraus, T. E., \& Fletcher, R. A. (1994). Paclobutrazol protects wheat seedlings from heat and paraquat injury. Is detoxification of active oxygen involved? Plant Cell Physiology, 35, 45-52. https://doi.org/10.1093/ oxfordjournals.pcp.a078569

Lin, K. H., Pai, F. H., Hwang, S. Y., \& Lo, H. F. (2006). Pre-treating Paclobutrazol enhanced chilling tolerance of sweetpotato. Plant Growth Regulation, 49, 249-262. https://doi.org/10.1007/s10725-006-9135-1

Mabvongwe, A., Manenji, B. T., Gwazane, M., \& Chandiposha, M. (2016). The effect of paclobutrazol application time and variety on growth, yield, and quality of potato (Solanum tuberosum L.), Advances in Agriculture. https://doi.org/10.1155/2016/1585463

McCready, R. M., Guggolz, J., \& Wens, H. S. (1950). Determination of starch and amylase in vegetables. Analytical Chemistry, 22, 1156-1158. https://doi.org/10.1021/ac60045a016

Moorby, J. (1970). The production, storage and translocation of carbohydrates in developing potato plants. Annals of Botany, 34(2), 297-308. https://doi.org/10.1093/oxfordjournals.aob.a084370

O’Brien, T. P., Feder, N., \& McCully, M. E. (1964). Polychromatic staining of plant cell walls by toluidine blue O. Protoplasma, 59(2), 368-373. https://doi.org/10.1007/BF01248568

Prakash, P., Chetti, M. B., \& Patil, S. S. (2001). Effect of plant regulators on growth parameters and yield in potato. Karnataka Journal of Agricultural Sciences, 14, 938-942. 
Rademacher, W. (2000). Growth retardants: Effects on gibberellins biosynthesis and others metabolic pathways. Annual Review of Plant Physiology and Plant Molecular Biology, 51, 501-531. https://doi.org/10.1146/ annurev.arplant.51.1.501

Rademacher, W., Spinelli, F., \& Costa, G. (2006). Prohexadione-Ca: Modes of action of a multifunctional plant bioregulator for fruit trees. Acta Horticulturae, 727, 97-106. https://doi.org/10.17660/ActaHortic. 2006.727.10

Rahman, M. N. H. A., Shaharuddin, N. A., Wahab, N. A., Wahab, P. E. M., Abdullah, M. O., \& Parveez, G. K. A. (2016). Impact of paclobutrazol on the growth and development of nursery grown clonal oil palm (Elaeis guineensis Jacq.). Journal of Oil Palm Research, 28(4), 404-414. https://doi.org/10.21894/jopr.2016. 2804.02

SAEG (Sistema de Análises Estatísticas e Genéticas). (2008). Universidade Federal de Viçosa. Versão 9.1 (CD-ROM). Viçosa, MG.

Sankar, B, Karthishwaran, R., \& Somasundaram, B. S. K. (2016). Leaf anatomical changes in peanut plants in relation to drought stress with or without paclobutrazol and ABA. Journal of Phytology, 5, 25-29.

Sebastian, B., Alberto, G., Emilio, A. C., Jose, A. F., \& Juan, A. F. (2002). Growth, development and color response of potted Dianthus caryophyllus cv. Mondriaan to paclobutrazol treatment. Scientia Horticulturae, 94(1-2), 371-377. https://doi.org/10.1016/S0304-4238(02)00005-5

Silva, F. L., Pinto, C. A. B. P., Alves, J. D., Benites, F. R. G., Andrade, C. M., Rodrigues, G. B., Lepre, A. L., \& Bhering, L. P. (2009). Caracterização morfofisiológica de clones precoces e tardios de batata visando à adaptação a condições tropicais. Bragantia, 68, 295-302. https://doi.org/10.1590/S0006-87052009000 200002

Sopher, C. R., Krol, M., Huner, N. P. A., Moore, A. E., \& Fletcher, R. S. (1999). Chloroplastic changes associated with paclobutrazol-induced stress protection in maize seedling. Canadian Journal of Botany, 77, 279-290. https://doi.org/10.1139/b98-236

Tekalign, T., \& Hammes, P. S. (2005). Growth responses of potato (Solanum tuberosum) grown in a hot tropical lowland to applied paclobutrazol: 1. Shoot attributes, assimilate production and allocation. New Zealand Journal of Crop and Horticultural Science, 33(1), 35-42. https://doi.org/10.1080/01140671.2005.9514328

Tsegaw, T., Hammes, S., \& Robbertse, J. (2005). Paclobutrazol-induced Leaf, Stem, and Root Anatomical Modifications in Potato. HortScience, 40(5), 1343-1346. https://doi.org/10.21273/HORTSCI.40.5.1343

Yeshitela, T., Robbertse, P. J., \& Stassen, P. J. C. (2004). Paclobutrazol suppressed vegetative growth and improved yield as well as fruit quality of 'Tommy Atkins' mango (Mangifera indica) in Ethiopia. New Zealand Journal of Crop and Horticultural Science, 32(3), 281-293. https://doi.org/10.1080/01140671. 2004.9514307

\section{Copyrights}

Copyright for this article is retained by the author(s), with first publication rights granted to the journal.

This is an open-access article distributed under the terms and conditions of the Creative Commons Attribution license (http://creativecommons.org/licenses/by/4.0/). 